\title{
Bibliometric Analysis of Researches on Digital Citizenship in Web of Science Database
}

\section{Research Article}

\section{Cengiz TASKIRAN ${ }^{1}$}

${ }^{1}$ Muş Alparslan University, Faculty of Education, Department of Social Science Education, Muş, Turkey, ORCID: 0000-0002-3677-6316

To cite this article: Taskiran, C. (2021). Bibliometric analysis of researches on digital citizenship in Web of Science database, International Online Journal of Educational Sciences, 13(2), 556-566.

\begin{tabular}{|c|c|}
\hline ARTICLE INFO & ABSTRACT \\
\hline Article History: & $\begin{array}{l}\text { The purpose of this study is to examine the scientific articles about digital citizenship in terms of } \\
\text { bibliometric indicators. Case study method, one of the qualitative research methods, was applied in }\end{array}$ \\
\hline Received: 01.01.2020 & $\begin{array}{l}\text { this present study. The scanning range of bibliometric data in the WoS database generated by } \\
\text { Clarivate Analytics covers the period between } 1975 \text { and December, 2019. The bibliometric analysis }\end{array}$ \\
\hline $\begin{array}{l}\text { Available online: } \\
\text { 03.03.2021 }\end{array}$ & $\begin{array}{l}\text { technique was conducted in the study. The studies were searched by writing "digital citizenship" in } \\
\text { the search engine of the WoS database. The analysis revealed that there were } 144 \text { studies related to }\end{array}$ \\
\hline & the digital citizenship registered in the WoS database between 1975 and 2019. It is concluded in these \\
\hline & records that education / training research is at the forefront. In the analysis, it was observed that the \\
\hline & most common type of publication related to digital citizenship was the articles with the total number \\
\hline & of 85 studies. Besides, it was determined that approximately $97 \%$ of the published articles were \\
\hline & $\begin{array}{l}\text { published in the last ten years. This rate indicates that the educational researches related to digital } \\
\text { citizenship have increased in recent years. }\end{array}$ \\
\hline
\end{tabular}

C 2021 IOJES. All rights reserved

Keywords:

Digital citizenship, Bibliometrics, Bibliometrics Analysis, Web of Science

\section{Introduction}

The concept of digital citizenship has emerged as a concept that has been included in both our daily life and scientific studies in recent years. The underlying reason for this is the rapid development of the digital world. The technological developments have removed the borders among the countries, and the world has also made a rapid pass to the digital citizenship. The rapid spread of the Internet thanks to the technological developments has brought with it the use of known citizenship rights in the digital environment and brought about new rights and rules in the digital environment. When the literature is examined, it is observed that the digital citizenship is defined as the behavioral norms that citizens are responsible for regarding the ability to participate in society online or the use of technology (Mossberger, Tolbert, \& S. Mc Neal, 2007). In other words, 
the digital citizenship is identified as the appropriate and responsible behavior norms in technological and virtual environments (Dere and Yavuzay, 2019 p. 2401). The digital citizenship defines the behavior of people in the working environments in such digital devices as computers, mobile devices, mobile phones, and tablets. In another saying, the standards regarding the appropriate use of digital citizenship technology are the use of information and communication technologies in accordance with the law and safe ethical standards. The individuals who are digital citizens have high-level thinking skills that can communicate on the internet and meet their needs over the internet. The individuals should act in accordance with safety, ethical rules, fast, or need in their behaviors in online settings (Sönmez \& Kocadağ Ünver, 2020). The way to conduct this is to comply with the standards defined as digital citizens. Although defined in different ways, the sub-dimensions of digital citizenship consist of nine sub-dimensions as stated by Ribble and Bailey (2011) in the literature. After the development of information technologies, these dimensions, including responsibilities that change according to needs, are explained as follows:

Digital Access: It is full electronic participation. It refers to providing digital access to technological possibilities equally so as to become productive citizens.

Digital Commerce: It is the online merchandise. Namely, it means having the ability to sell and buy in digital media.

Digital Communication: It is electronic information exchange. People should be aware that their communication patterns have changed and that they are now communicated through the electronic means, and they should make use of these means correctly.

Digital Literacy: It refers to knowing when and how to use digital technology. It is also that people are aware that their educational activities are now carried out by using technology.

Digital Ethics: They are the standards of behavior expected by other digital technologies. Moreover, they are that the individuals are aware that the behaviors shown in the virtual world have an electronic standard.

Digital Law: It is the legal rights and restrictions governing technology. One must know that the work done in the virtual environment has an electronic responsibility and a legal sanction.

Digital Rights and Responsibilities: They are the privileges provided to the digital users, freedoms, and behavioral expectations that come with all the digital users.

Digital Health: It is the awareness that there are factors that directly or indirectly affect the health in the digital world physically, mentally, and psychologically.

Digital Security: These are the measures that must be taken to ensure the personal security of all technology users and networks.

Such sub-dimensions as digital access, digital commerce, digital communication, digital literacy, digital ethics, digital law, digital health, digital security, digital rights and responsibilities also constitute the basis of digital citizenship. Besides, the digital citizenship is expressed as the norms regarding the use of basic information technologies, and it is known that there are no written rules for these norms. On the other hand, a framework is presented in the process of using and developing technology (Kocadağ, 2012). When the way of defining digital citizenship, the proposed rules, or the framework is examined, it can be mentioned that there are a number of skills that citizens need to apply successfully (Conley, 2010). Considering the subdimensions of digital citizenship, especially in the security dimension, it is stated that technology cannot be used correctly and without error, just like the inability to drive a vehicle without a driver license and without sufficient awareness (Kocadağ, 2012). Therefore, Prensky (2010) recommends that the skills related to digital citizenship should be taught accurately and completely. Also, considering the sub-dimensions of digital citizenship, it is stated that the most difficult area for individuals is digital ethics (Sönmez \& Kocadağ Ünver, 
2020). By preventing misbehavior, it will be possible to prevent the violation of personal rights of individuals and to raise the awareness that each individual can affect other individuals as being responsible (Karaman et al., 2009). Moreover, the digital ethics process will be accelerated through the regulations on intellectual and industrial rights (Karaman et al., 2009).

When the literature is reviewed, it is seen that the researches carried out by Prensky (2001), Ribble, Bailey, Ross (2004), Mossberger, Tolbert, and Mc Neal (2007) Eid and Ward (2009), Çarıkçı (2010), Ribble (2011), Kocadağ (2012), Ohler (2012), Çubukcu and Bayzan (2013), İşman and Güngören, Ö. C. (2014), Karaduman and Öztürk (2014), Choi (2016), Karaduman, Köse and Eryılmaz (2017), Ünal Dilşat, P. (2017), Çakmak and Aslan (2018), Dere and Yavuzay (2019), Yalçınkaya and Cibaroğlu, M. O. (2019) and Aygun and Ilhan (2020) are the studies covering digital citizenship and its sub-dimensions. When these studies in the literature are examined, a general bibliometric analysis including digital citizenship, which constitutes the content of this research, has not been found. The bibliometric analysis to be performed will be the analysis of the field and will be guiding the scientists who will conduct studies on the field from now on. In this regard, in this study, the state of scientific articles about digital citizenship has been tried to be revealed in terms of bibliometric indicators.

Accordingly, the research questions to be answered in the study are as follows:

What are the WoS categories of the publications scanned with the keyword "digital citizenship" within the scope of Education/Training research?

What are the types of publications related to digital citizenship within the scope of Education/Training research?

What is the distribution of articles published on digital citizenship in the Education/Training research category by publication years?

Who and what are the authors and the number of publications that make the most contribution to the field within the scope of digital citizenship in the Education/Training research category?

Which institutions are active within the scope of articles published on digital citizenship in the Education/Training research category?

What are the top 10 most-cited articles on digital citizenship in the Education/Training research category?

Who are the authors active within the scope of articles published on digital citizenship in the Education/Training research category?

\section{Method}

\section{Research Design}

The model of the research is a case study from qualitative research designs. The purpose in the case study is to reveal the results related to a particular situation (Yıldırım \& Şimşek, 2011). Since it is purposed in this study to determine the present status of the educational researches published in the field of digital citizenship, the study was designed in case study approach.

\section{Data Collection}

The data of this study was obtained by using Web of Science, one of the international citation indexes. The data was acquired by searching with the keyword "values education" both in the article titles and in the article content. An online scan was conducted in the WoS database covering the dates between 1975 and October, 10, 2019. The scanned indexes were determined as SCI-Expanded, SSCI, A \& HCI, CPCI-S, CPCI- 
SSH, BKCI-S, BKCI-SSH, and ESCI. Web of Science makes a significant contribution to bibliometric studies as a database containing bibliometric data related to scientific publications scanned in these indexes (Güzeller and Çeliker, 2017 p. 89). A total of 144 records were revealed during this screening process. Most of these records are in the scope of education/training researches, and the study in question is limited to the article with the most record types. The obtained findings are presented in tables.

\section{Data Analysis}

Bibliometrics was used as the data analysis technique in the study. The term of bibliometrics refers to the mathematical and statistical analysis of models that appear in publications and document types (Diodato, 1994). The methods used in bibliometric analysis can be summarized as citation index, bibliographic matching, co-citation analysis, and bibliometric mapping method (Polat, Saraçoğlu and Duman, 2019 p. 47). Accordingly, such questions as "What are the WoS categories of the publications scanned with the keyword "digital citizenship" within the scope of Education/Training research?, What are the types of publications related to digital citizenship within the scope of Education/Training research?, What is the distribution of articles published on digital citizenship in the Education/Training research category by publication years?, Who and what are the authors and the number of publications that make the most contribution to the field within the scope of digital citizenship in the Education/Training research category?, Which institutions are active within the scope of articles published on digital citizenship in the Education/Training research category?, What are the top 10 most-cited articles on digital citizenship in the Education/Training research category?, and Who are the authors active within the scope of articles published on digital citizenship in the Education/Training research category?" were analyzed as variable in this study. WoS categories of 891 studies that emerged as a result of online scanning were examined. In the study, the keyword network map was made by using the VOSviewer (Version 1.6.9) package program.

\section{Findings}

WoS categories of 144 studies that emerged as a result of online scanning were examined, and the top 10 categories are presented in Table 1.

Table 1. WoS Categories of Publications Scanned with the Keyword "Digital Citizenship" (Top 5 categories)

\begin{tabular}{lc}
\hline WoS Categories & Number of Records \\
\hline 1. Education/Training Research* & 75 \\
2. Communication & 20 \\
3. Social Sciences & 23 \\
4. Multi-Fielded Human Sciences & 19 \\
5. Social Subjects & 7 \\
\hline
\end{tabular}

When Table 1 is examined, it is observed that the most records are in the "Education/Training Researches" category with 75 studies, and this category is followed by communication with 20 studies, social sciences with 23 studies, multi-fielded human sciences with 19 studies, and social subjects with 7 studies.

The publications in the Education/Training Research category were examined according to their types and presented in Table 2.

Table 2. Types of Publications on Digital Citizenship within the Scope of Education/Training Research

\begin{tabular}{lc}
\hline WoS Categories & Number of Records \\
\hline 1. Article & 85 \\
2. Chapter of Book & 28 \\
3. Paper & 16 \\
4. Book Review & 5
\end{tabular}


5. Editor Note

When Table 2 is examined, it is observed that the most publication type is the articles with 85 studies. This type is followed by 28 book chapters, 21 papers and 10 book reviews.

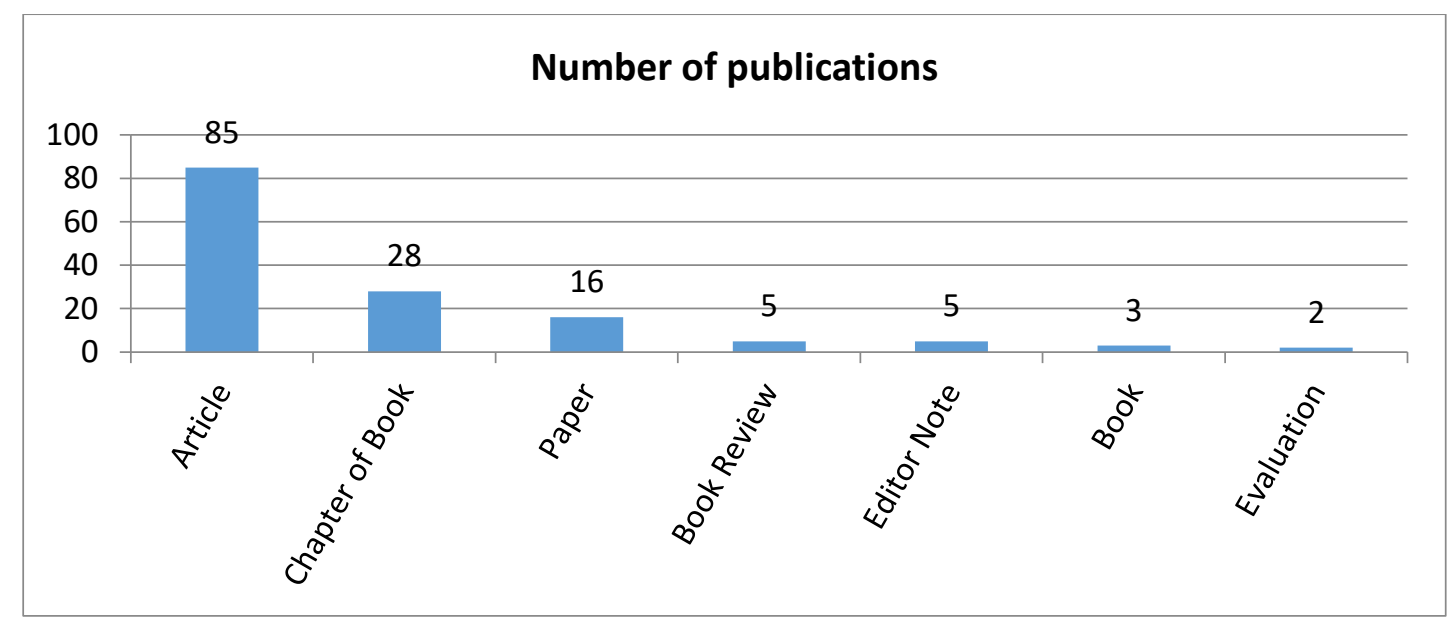

Graphic 1. Types of Digital Citizenship Publications within the Scope of Education / Training Research

The keywords of the articles related to digital citizenship in the Education / Training Research category are examined and the keyword network is presented in Graphic 2.

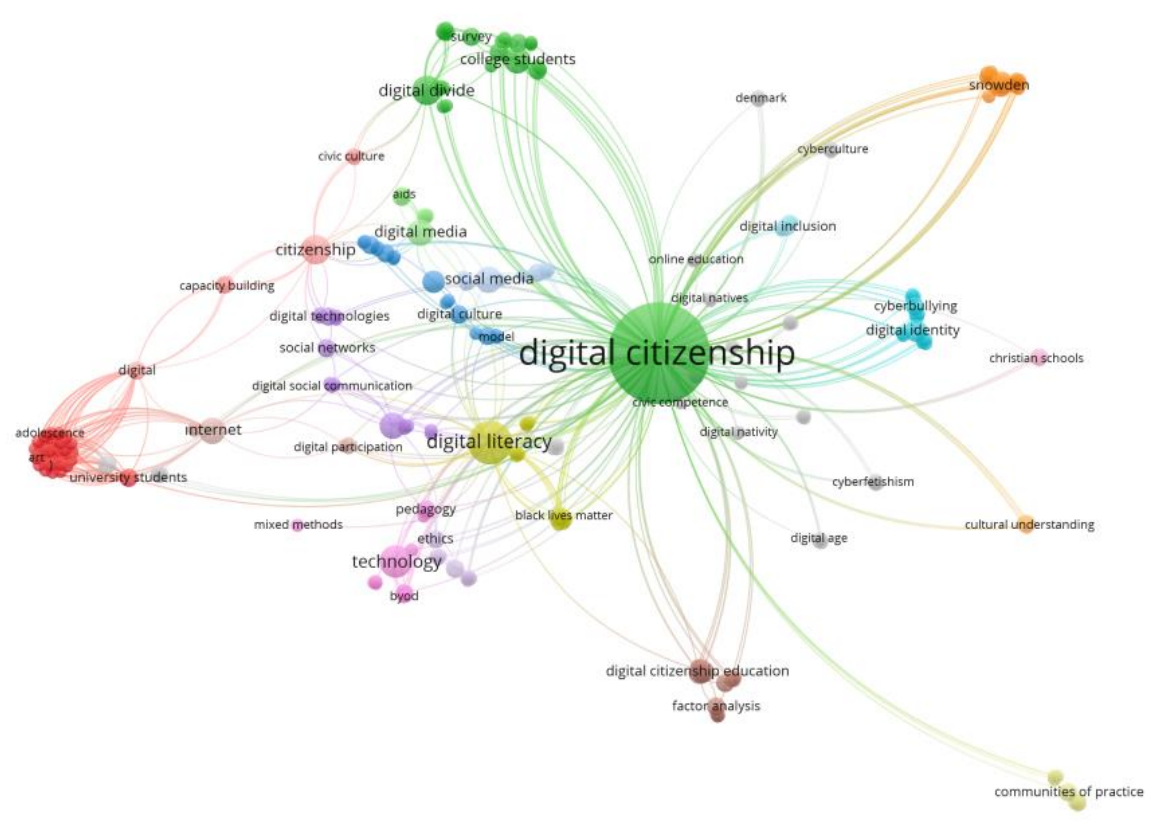

Graphic 2. Keywords and current subject analysis ( $\mathrm{N}=144)$

When Graphic 2 is analyzed, it is observed that the most-used keywords in the articles tend towards such keywords as digital citizenship, digital literature, technology, digital division, citizenship, internet, digital media, education, social media, and digital citizenship education. 
The distribution of the articles published on digital citizenship in the Education/Training Research category by the publication years was examined and given in Table 3.

Table 3. Distribution of Articles Published on Digital Citizenship in Education/Training Research Category by Publication Years $(\mathrm{N}=144)$

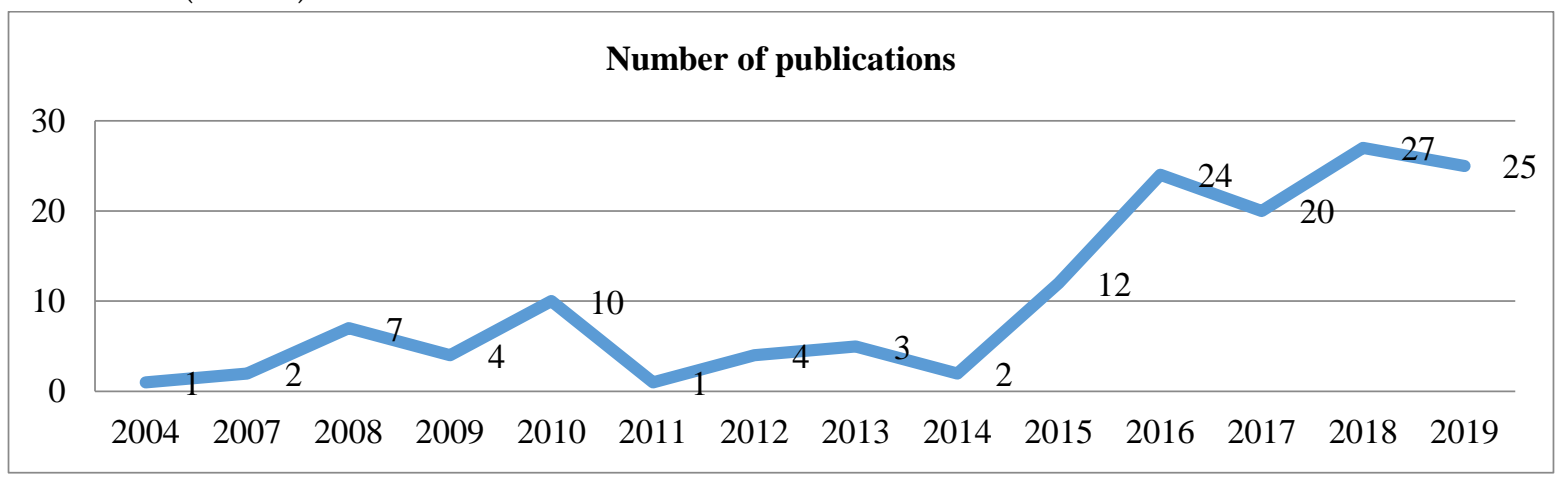

Considering the articles published on digital citizenship in the Education/Training Research category, it was observed that most of the articles were published in 2018 (27 articles). It was determined that this is respectively followed by 2019 (25 articles), 2016 (24 articles), and 2015 (12 articles). It is observed that $64.27 \%$ (108 articles) of the published articles have been published in the last five years.

Within the scope of articles published on digital citizenship in the Education/Training Research category, the researchers and the number of publications that contributed most to the field were examined and provided in Table 4.

Table 4. Number of Authors and Publications Contributing to the Field Most Within the Scope of Digital Citizenship in the Education / Educational Research Category ( $\mathrm{N}=144)$

\begin{tabular}{lc}
\hline Authors & Number of Records \\
\hline 1. MOSSBERGER K & 7 \\
2. TOLBERT CJ & 7 \\
3. FARMER LSJ & 5 \\
4. MCNEAL RS & 5 \\
5. XU S & 5 \\
6. YANG HH & 5 \\
7. MACLEOD J & 4 \\
8. ZHU S & 4 \\
9. CHOI M & 3 \\
10. MUSGRAVE ML & 3 \\
\hline
\end{tabular}

When Table 4 is examined, it is clearly seen that the authors contributing to the field most are respectively Mossberger K. and Tolbert CJ (7 Articles), Farmer LSJ, Mcneal RS, Yang HH and Xu S (5 Articles), Macleod J and Zhu S (4 Articles), and Choi M and Musgrave (3 Articles).

Table 5. Institutions Effective within the Scope of Studies Published on Digital Citizenship in the Education/Training Research Category $(\mathrm{N}=144)$

\begin{tabular}{lcc} 
& Institutions & Number of Records \\
\hline California State University & 10
\end{tabular}


Complutense University Of Madrid 3

Ohio State University 3

Universidad De Almeria 3

University Of Sevilla 3

Arizona State University 2

When the institutions in Table 5 that are active within the scope of published studies on Digital Citizenship in the Education / Educational Research Category are examined, it is seen that such universities in the United States as California State and State University of New York are in the first rank with 10 studies. Central China Normal University and Huanggang Normal University in the People's Republic of China conducted 5 studies each. Then comes Cardiff University from England and Complutense University of Madrid University from Spain with 3 studies each. Arizona State University in the United States comes with 2 studies at $10^{\text {th }}$ rank in the top 10 university list. These results also show us the conclusion that the digital citizenship studies are in direct proportion with technological advances.

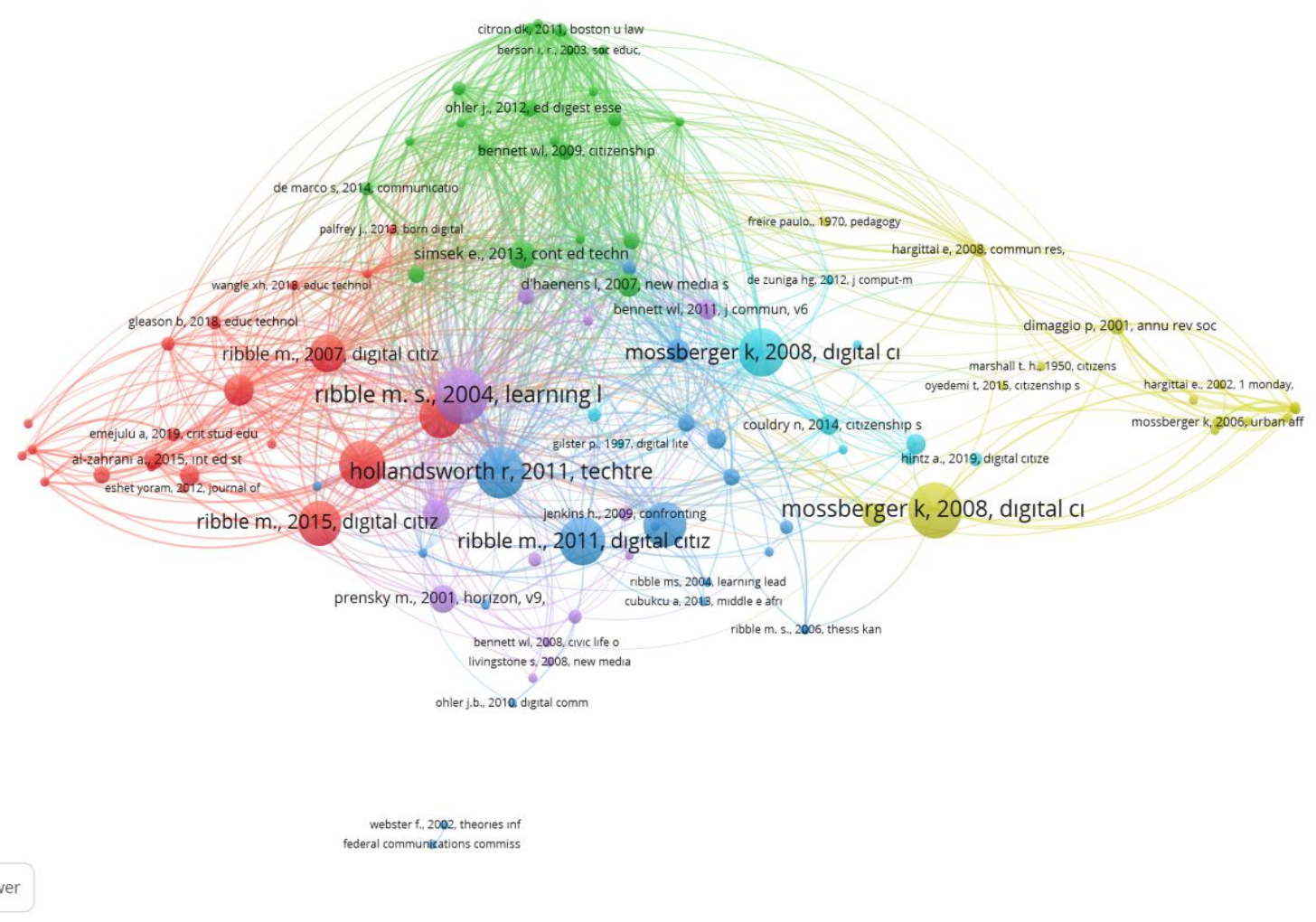

Graphic 3. Most-Cited Resources and Citation Networks $(\mathrm{N}=144)$

Table 6. Most-Cited Resources in Studies Related to Digital Citizenship in Education / Educational Research Category (N $=144)$

\begin{tabular}{lc}
\hline Authors & Number of Citations \\
\hline 1. Ribble, M (2004) & 16 \\
2. Mosserberger, K.(2008) & 16 \\
\hline
\end{tabular}




\begin{tabular}{lc}
\hline 3. Hollandsworth, R. (2011) & 15 \\
4. Jones, M. (2016) & 14 \\
5. Choi, M. (2016) & 13 \\
6. Ribble, M (2015) & 13 \\
7. Mosserberger, K (2007) & 8 \\
8. Ribble, M (2007) & 8 \\
9. Choi, M. (2017) & 8 \\
\hline 10.Şimşek, E. (2013) & 7 \\
\hline
\end{tabular}

When Table 6 is examined, it is seen that the resources by Ribble, M. (2004) and Mosserberger, K. (2008) are the most-cited resources with 16 citations. And, the ranking continues as Hollandsworth, R. (2011) with 15 citations and Jones, M. (2016) with 14 citations.

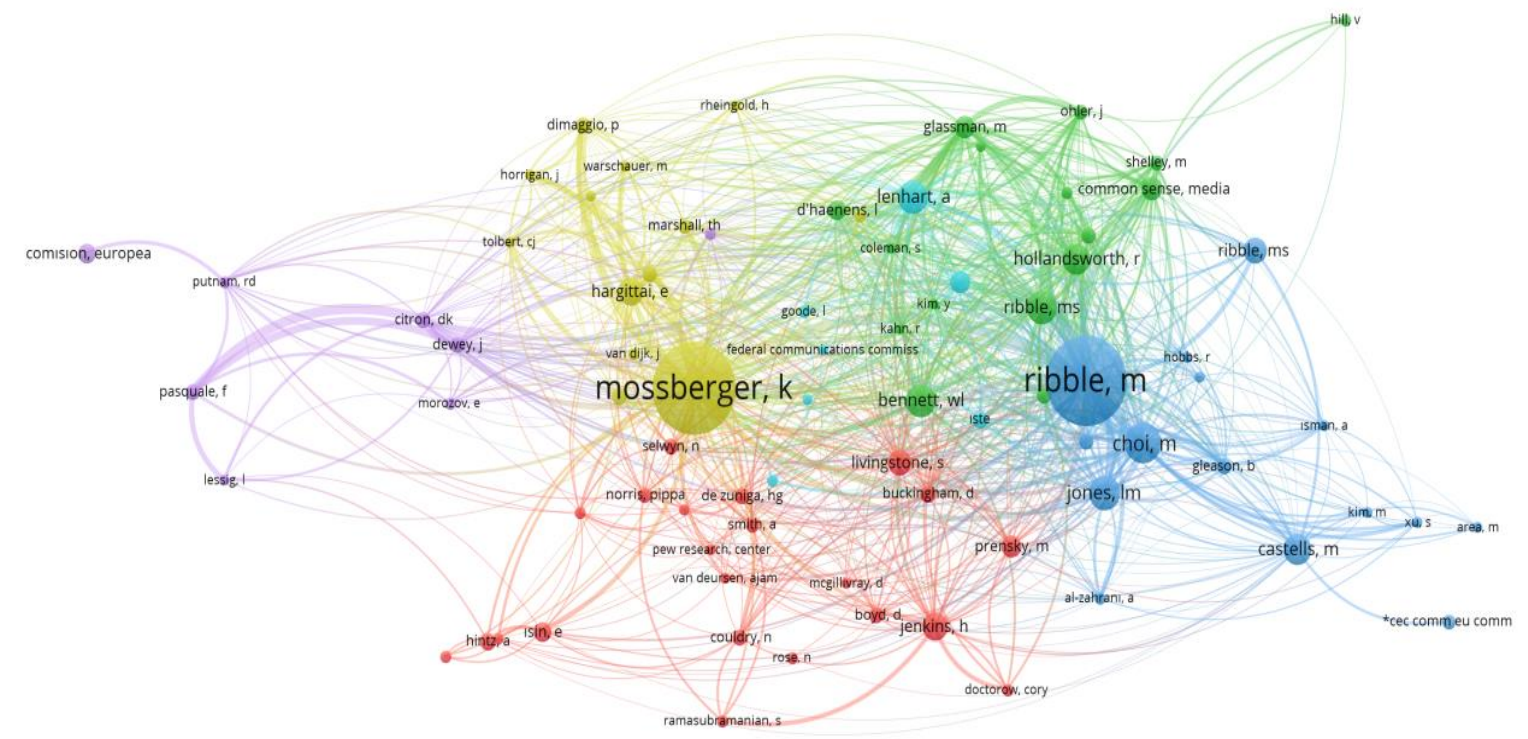

\section{\& vosviewer}

Graphic 4. The Most-Cited Authors

Table 7. The Most-Cited Authors in Studies Related to Digital Citizenship in Education/Training Research Category

\begin{tabular}{lc}
\hline Authors & Number of Records \\
\hline 1. Mosserberger, K. & 69 \\
2. Ribble, M. & 66 \\
3. Choi, M. & 25 \\
4. Jones, M. & 20 \\
5. Bennett, WL. & 19 \\
6. Ribble, MS. & 19 \\
7. Lenhart, A. & 19 \\
8. Hollandsworth, R. & 18 \\
9. Castells, M. & 18 \\
10. Hargittai, E. & 16 \\
\hline
\end{tabular}


When Table 7 is examined, it is seen that the table is listed as Mosserberger with 69 citations, Ribble with 66 citations, Choi with 25 citations, Jones with 20 citations, Bennett and Ribble with 19 citations.

\section{Conclusion and Discussion}

The concepts that are defined as digital native and digital immigrant (Prensky, 2001) in the literature are currently grouped according to the direct or indirect acquaintance of individuals with technology. Whereas the digital natives meet technology as soon as they are born, the digital immigrants try to adapt to technology later. Considering the frequency of using information technologies and the internet, it is important for citizens, whether they are digital natives or digital immigrants, to easily access the information they need in these environments and to perform their transactions safely (Sönmez \& Kocadağ Ünver, 2020). The use of the internet through the social, cultural, educational, or entertaining aspects by the citizens is valuable in terms of the consequences of the behaviors displayed in this process. Therefore, digital citizenship is the focus of attention of researchers as a subject that should be explored. Thanks to this study, it was concluded that 144 of the studies recorded in WoS Database between 1975 and 2019 were related to digital citizenship. It was observed that 85 (85\%) of these studies were included in the category of education/training research. The fact that education/training research is at the first rank in the WoS database indicates that the intensive studies are carried out in the field of digital citizenship. It is recommended that the researchers who intend to study on the digital citizenship should also consider this result. It was also seen in the analysis that the most common type of publication related to digital citizenship is the articles with 85 studies. It can be stated that they are frequently preferred because the scientific articles are a type of publication that the scientists making scientific studies benefit from. In addition to this aspect, it can be mentioned that this type of publication is mostly preferred since the scientists evaluate their academic studies in the form of article. As a matter of fact, there are studies in the literature with similar findings (Chao, Yang and Jen, 2007; Karagöz and Şeref, 2019; Trapero , Parra \& Martínez 2020, Tsay and Yang, 2005). Even though articles are mostly prepared for digital citizenship, it will also be appropriate to carry out thesis and make presentations in scientific conferences. According to another finding, a total of 78 different keywords were used in 94 articles. It is determined that the most-used keywords in the articles are digital citizenship, digital literature, technology, digital division, citizenship, internet, digital media, education, social media, and digital citizenship education.

It was detected that the most articles (27 articles) in the category of education/training research related to digital citizenship were published in 2018. It was also revealed that $64 \%$ of the published articles were published in the last five years. For this rate, it can be asserted that the educational researches related to digital citizenship have been included in recent years. According to another analysis result, it was determined that the authors contributing most to the field were respectively "Mosserberger, K.", "Rıbble, M.", "Choi, M.", and "Jones, M."

This study explored the articles related to Digital Citizenship research category in WoS database. In this context, in terms of delimitation it could be expressed that the study involves the studies included solely in the WoS database. Considering that this study was conducted on the articles listed on "Digital Citizenship " in WoS, bibliometric studies can be suggested for other disciplines of educational environments. 


\section{REFERENCES}

Aşkar, P. \& Akkoyunlu, B., (2007). Okullarda bilişim teknolojileri ve öğretmen yetiştirme politikaları: türkiye deneyimine tarihsel bir bakış, Uluslararası Öğretmen Yetiştirme Politikaları ve Sorunları Sempozyumu, Mayıs, Bakü (2007), Bildiriler Kitabı.

Aygun, M., \& Ilhan, G. O. (2020). Analysis of in-Service and Pre-Service Social Studies Teachers' Digital Citizenship, International Online Journal of Educational Sciences, 12(4), 123-146.

Chao, C. C., Yang, J. M., \& Jen, W. Y. (2007). Determining technology trends and forecasts of RFID by a historical review and bibliometric analysis from 1991 to 2005. Technovation, 27(5), 268-279.

Choi, M. (2016). A concept analysis of digital citizenship for democratic citizenship education in the internet age. Theory and Research in Social Education, 44(4), 565-607.

Conley, K. (2010). We're Not in Kansas Anymore. Learning \& Leading with Technology, March/April 2010, 5. Correlation to CyberSmart! Workshop (2007). Online Professional Development to ISTE National Educational Technology Standards for Students: The Next Generation.

Çakmak, Z.\&Aslan, S. (2018). Sosyal bilgiler öğretmen adaylarının dijital vatandaşlık davranışlarının bazı değişkenler açısından incelenmesi. Adıyaman Üniversitesi Eğitim Bilimleri Dergisi, 8(1), 72-99.

Çarıkçı, O. (2010). Türkiye'de E-devlet Uygulamaları Üzerine Bir Araştırma. Süleyman Demirel Üniversitesi Sosyal Bilimler Enstitüsü Dergisi, 2(12), 95-122.

Çubukcu, Ş. \& Bayzan, Ş. (2013). Türkiye'de Dijital Vatandaşlık Algısı ve Bu Algıyı İnternetin Bilinçli, Güvenli ve Etkin Kullanımı ile Artırma Yöntemleri. Middle Eastern \& African Journal of Educational Research, $5(3), 25-31$.

Dere, İ. \& Yavuzay, M. (2019). Sosyal Bilgiler Öğretmen Adaylarının Dijital Vatandaşlık Göstergelerinin İncelenmesi. Manas Sosyal Araştırmalar Dergisi, 8(3), 2400-2414.

Diodato V. (1994). Dictionary of Bibliometric. Haworth Press: Binghamton, NY.

Eid, M. \& Ward, S. (2009). Ethics, New Media and Social Networks. Global Media Journal, 2(1), 1-4.

Güzeller, O.S. \& Çeliker, N. (2017). Geçmişten Günümüze Gastronomi Bilimi: Bibliyometrik Bir Analiz, Journal of Tourism and Gastronomy Studies, 5(2), 88-102.

Görmez, E. (2017). İlkokul Sosyal Bilgiler Programının Dijital Vatandaşlık ve Alt Boyutları Açısından Yeterliliği. The Journal of Academic Social Science Studies, 60(3), 1-15.

Karaduman, H. \& Öztürk, C. (2014). Sosyal Bilgiler Dersinde Dijital Vatandaşlığa Dayalı Etkinliklerin Öğrencilerin Dijital Vatandaşlık Tutumlarına Etkisi ve Dijital Vatandaşlık Anlayışlarına Yansımaları. Journal of Social Studies Education Research, 5(1), 38-78.

Karaduman, H., Çengelci Köse, T. \& Eryılmaz, Ö. (2017). Sosyal Bilgiler Öğretmen Adaylarına Göre Sosyal Medyada Değerler. Turkish Online Journal of Qualitative Inquiry, 8(2), 250-271.

Karagöz, B. \& Şeref, I. (2019). Yunus Emre ile İlgili Araştırmaların Bibliyometrik Analizi. Akdeniz Eğitim Araştırmaları Dergisi, 13(27), 123-141.

Karaman, M. K., Ekici, M. \& Karabulut, B. (2009). Dijital Vatandaşlık, I. Uluslararası Avrupa Birliği, Demokrasi, Vatandaşlık ve Vatandaşlık Eğitimi Sempozyumu, Uşak.

Kocadağ, T. (2012). Determining the Digital Citizenship Levels of Prospective Teachers. [Unpublished master's thesis]. Karadeniz Teknik University. Thesis Number:321888 https://tez.yok.gov.tr/. 
Mossberger, K., Tolbert, C., \& S. McNeal, R. (2007). Digital Citizenship: The Internet, Society, and Participation. London, England: The MIT Press.

Özoğul, P. (2006). Problems that computer teachers meet in their professional lives: a case in eskisehir. [Unpublished master's thesis]. Institute of Educational Science, Anadolu University. Thesis Number:257117 https://tez.yok.gov.tr/.

Polat, A.Z., Saraçoğlu, A. \& Duman, H. (2019). Harita Dergisi'nin Bibliyometrik Analizi, Harita Dergisi, 16(1), 46-56.

Ribble, M. (2004). Digital Citizenship: Addressing Appropriate Technology Behavior. Learning and Leading with Technology, 32(1), 6-11.

Ribble, M. \& Bailey, G. (2007). Digital Citizenship In Schools. Washington, DC: International Society for Technology in Education.

Ribble, M. (2011). Digital Citizenship in Schools. International Society for Technology in Education: Washington.

Sönmez, Ö. F. \& Kocadağ Ünver, T. (2020). Dijital Vatandaşlık ve Sosyal Bilgiler Eğitimi. R. Turan ve H. Akdağ. (Ed.), 1. Baskı içinde, Sosyal Bilgiler Öğretiminde Yeni Yaklaşımlar IV (139-152). Ankara: Pegem Akademi.

Ünal Dilşat, P. (2017). Bir Öğretim Programındaki Dijital Vatandaşlık Öğeleri ve Ortaöğretim Öğrencilerinin Dijital Vatandaşlık Ögelerine Sahip Olma Durumları, Karaelmas Journal of Educational Sciences, 5(2), 180-195.

Prensky, M. (2001). Digital Natives, Digital Immigrants Part 1. On the Horizon, 9(5), 1-6.

İşman, A. \& Güngören, Ö. C. (2014). Digital Citizenship. TOJET: The Turkish Online Journal of Educational Technology, 13(1), 73-77.

Trapero F.G.A., Parra J.C.V. \& Martínez M.J.G. (2020). Digital citizenship approach and teacher profile. Education in the Knowledge Society, 21(6), 1-11.

Tsay, M. Y.,\&Yang, Y. H. (2005). Bibliometric analysis of the literature of randomized controlled trials. Journal of the Medical Library Association, 93(4), 450-458.

Yalçınkaya, B. \& Cibaroğlu, M. O. (2019), Dijital Vatandaşlık Algısının İncelenmesi: Ampirik Bir Değerlendirme, BMIJ, 7(4), 1188-1208

Yıldırım, A. \& Şimşek, H. (2011). Sosyal bilimlerde nitel araştırma yöntemleri. Ankara: Seçkin Yayıncılık. 